\title{
Importance of international networking in academic family medicine
}

\begin{abstract}
Zalika Klemenc-Ketiš, Janko Kersnik
Department of Family Medicine, Medical

School, University of Maribor, Slovenia

Corresponding author:

Zalika Klemenc-Ketiš

Kersnikova 1

3320 Velenje

Slovenia

zalika.klemenc-ketis@uni-mb.si

Tel.: + 38641516067

Fax.: +38659030250

Received: 19 June 2013

Accepted: 22 October 2013

Copyright (c) 2014 by

Academy of Sciences and Arts

of Bosnia and Herzegovina.

European family medicine/general practice (FM/GP) has travelled the long and successful journey of profiling the discipline and has produced valuable position papers on education and research. Nowadays, academic medicine is one of the pillars in the future development of FM/GP in Europe. A common European curriculum on undergraduate and postgraduate family medicine is needed. Also, a sound international platform of teaching institutions and/or teachers of family medicine would foster the further development of family medicine as an academic discipline. This would stimulate students and teachers to engage in international exchange to gain new knowledge and experiences, present their work and ideas abroad and prepare the conditions for further exchange of students and teachers. Conclusion. Established departments of FM/GP, led by a teacher who is a family physician/general practitioner, at each Medical School in Europe should provide students with knowledge and skills related to the core attributes of FM/GP. International exchanges of teachers and students should foster the development of a common curriculum on FM in Europe and foster improvement in the quality of FM education.
\end{abstract}

E-mail for permission to publish:

amabih@anubih.ba
Key words: Family practice, Education, Network, Exchange.

\section{Introduction}

European family medicine/general practice (FM/GP) has travelled the long and successful journey of profiling the discipline (1) and has produced valuable position papers on education (2) and research (3). But the turmoil inherent to the medical field, with its subspecialisation and educational and research egoism has also shaken the field of academic family medicine. The European Academy of Teachers (EURACT), besides its Educational Agenda (2) has also developed criteria for the selection process, criteria for trainers and teaching institutions, which have been to a great extent incorporated into the curricula of specialist training in the majority of European countries (4) and are a framework for the continuing educational development of trainers in family medicine (5), but we still lack a common curriculum for undergraduate (6) and postgraduate studies in family medicine (7).

The exchange of students, because of the demands for a lengthy period of stay, is limited to those who are willing to stay abroad for one semester or more (8), but not for a few weeks, or as long as the teaching block in family medicine takes. Also, there is no common platform for exchanging university 
teachers in Europe. These facts are the major obstacles for the further development of family medicine teaching and the discipline in general.

The aim of this article was to review the current situation in FM education in Europe and to present the possibilities of international networking.

\section{Current situation}

When looking behind the curtains of the podium disputes, we can identify three major risk factors for future stagnancy in the development of European FM/GP $(9,10)$ :

1. The lack of common goals. This threat may be identified on the international level as the difference between countries in terms of size, health care system, position of FM/ GP and the development of FM/GP (11). It is also seen inside individual countries, where everybody is busy with his/her own institution, organisation or a research project, but fails to recognise common goals. The multitude of family medicine textbooks in use also implies the lack of common goals (12).

2. Diversification of objectives. On the international level, one may observe this in the multitude of formal and informal networks and special interest groups (13) - all striving for justified individual FM/GP objectives, with little or no cohesion. This also happens within national contexts. Societies and colleges fight for the appropriate position of FM/GP within the national health services, emphasising the financial aspects and mandatory specialty training in FM/GP. On the other hand, university FM/GP teaching staff are busy working with students, protecting their own positions within the tough medical school environment and caring for their own staff. This leads to a lack of FM/GP representatives in national and international FM/GP bodies and organisations, which may negatively affect the position and development of the profession itself.
3. Asymmetric power distribution. The European Society of General Practice/Family medicine (WONCA Europe) is a large organisation, with an acceptable budget but few of its own large projects, relying mainly on networks and special interest groups, which sometimes pursue their own individual FM/GP goals, which are not necessarily always in line with the WONCA Europe mission. The Council seeks opportunities to diminish their differences by mixing the composition of the executive board, which cannot add much to their future development. Identical problems are found within individual countries, where in developed countries we can see a hidden or overt struggle between practitioners, professional organisations, regulatory bodies, universities, etc., and in less developed countries, the development of the academic science is usually overwhelmed in the struggle for financial recognition for FM/GP work.

\section{Why is networking needed}

The level of the "development" of the discipline in Europe is mainly measured through the successes of a few countries, thus putting the less well-developed and those not able to promote or adequately measure their development at the tail end of professional improvement of FM/GP in the world. This can lead to exposing the whole discipline to the risk that individual universities would try to squeeze out departments of FM/GP and replace them with more scientifically productive medical (sub)specialities, leading to even more sub-specialised curricula and less comprehensive and holistic education (4). We have to take into account that, in the absence of a clear position of the FM/GP profession regarding the content and objectives of FM/GP teaching in medical schools, heads of departments are sometimes not experts in FM/GP but they come from other disciplines (14). As such, they are usually 
under pressure from the Dean, who usually compares his own faculty with other faculties. This can result in the situation where FM/GP in that university is not in an optimal position. A formal position statement accepted by WONCA would improve the situation on this issue (10).

Moreover, the first two strategic goals published on the official WONCA Europe website (15), i.e.: 1) Mandatory undergraduate education in FM/GP at all medical schools in Europe and 2) Academic departments of FM/GP at all university medical schools in Europe, still have to be accomplished at many European Universities (16). We can claim that FM/GP in Europe may become a victim of its own success. In the nineteen-seventies, we had a common goal with a few objectives. However, the developments in the nineties brought us to the point where some countries enjoyed a victorious position and others just saw a reflection of their aims (through these countries). Finally, the new millennium brought changes to all of us (10). The position of FM/GP is under heavy debate and financial pressure, mainly from the health authorities. To turn threats into opportunities, we need to establish a sound platform to aid the sustainability of teaching activities in the future.

\section{Possibilities of international networking}

A broad project consortium of experienced partners/teachers from all over Europe, together with the involvement of the two WONCA Europe existing networks, especially EURACT, that includes representation of 41 European countries, with over 800 direct members, would assure that the network for FM/GP academic collaboration in Europe will be sustainable for longer. Its objectives could include several items (Box 1) (10).
Box 1:

1. Promotion of common family medicine content and context in Medical Schools' curricula (17).

2. Networking and collaboration in the field of basic medical education

3. Platform for the exchange of curricula, programmes, projects in undergraduate and postgraduate education.

4. Network for student and teacher exchanges (8).

5. Collaboration with other WONCA networks, special interest groups (SIGs) and different regional networks.

6. Teaching agenda for undergraduate education (17).

7. Quality improvement of undergraduate and postgraduate teaching (7).

8. Teaching teachers' courses.

9. Research in postgraduate education.

10. Innovative approaches in undergraduate teaching $(18,19)$.

11. Support to less developed departments/medical schools.

12. Core family medicine curricula for basic medical education (17).

Good examples from family practice specialization training development could serve as a benchmark in these processes (2, 20). An example of successful collaboration is the assistance for family practice training development in Montenegro, where foreign experts helped to introduce an improved curriculum of family medicine (21).

\section{Practical examples of successful networking}

The Department of Family Medicine of the Maribor Medical School (22) and the Department of Family Medicine from Zagreb Medical School have a long tradition in the international exchange of students and teachers. It started in the $2007 / 2008$ academic year when students and teachers from Maribor arrived in Zagreb for a one-day study visit, presenting curricula and student assignments. Until December 2012, these exchange visits were bilateral. On the last exchange visit, the Department of Family Medicine from Ljubljana Medical School joined us. 
Table 1 Aims of exchange visits for students and teachers

\begin{tabular}{l}
\hline Aim \\
Learning about foreign medical schools.
\end{tabular}

Table 2 Networking in Maribor Department of Family Medicine

\begin{tabular}{|c|c|c|c|c|c|c|c|}
\hline $\begin{array}{l}\text { City of } \\
\text { networking }\end{array}$ & Belgrade & Graz & Ljubljana & Podgorica & Sarajevo & Skopje & Zagreb \\
\hline $\begin{array}{l}\text { Type of } \\
\text { co-operation }\end{array}$ & $\begin{array}{l}\text { Teachers' } \\
\text { exchange }\end{array}$ & $\begin{array}{l}\text { Teachers' } \\
\text { exchange }\end{array}$ & $\begin{array}{l}\text { Exchange } \\
\text { of teachers, } \\
\text { students and } \\
\text { researchers }\end{array}$ & $\begin{array}{l}\text { Teachers' } \\
\text { exchange }\end{array}$ & $\begin{array}{l}\text { Teachers' } \\
\text { exchange }\end{array}$ & $\begin{array}{l}\text { Teachers' } \\
\text { exchange }\end{array}$ & $\begin{array}{l}\text { Exchange of } \\
\text { teachers, students } \\
\text { and researchers }\end{array}$ \\
\hline Project/s & $\begin{array}{l}\text { Visiting } \\
\text { professorship }\end{array}$ & $\begin{array}{l}\text { Visiting } \\
\text { lectures }\end{array}$ & $\begin{array}{l}\text { Research } \\
\text { projects }\end{array}$ & $\begin{array}{l}\text { Visiting } \\
\text { lectures, } \\
\text { trainees' } \\
\text { assessment }\end{array}$ & $\begin{array}{l}\text { Visiting } \\
\text { lectures }\end{array}$ & $\begin{array}{l}\text { Visiting } \\
\text { lectures, } \\
\text { trainees' } \\
\text { assessment }\end{array}$ & $\begin{array}{l}\text { Students' } \\
\text { conferences, } \\
\text { teachers' } \\
\text { conferences, } \\
\text { research projects }\end{array}$ \\
\hline Content & Lectures & Lectures & Research & $\begin{array}{l}\text { Lectures, } \\
\text { assessment }\end{array}$ & Lectures & $\begin{array}{l}\text { Lectures, } \\
\text { assessment }\end{array}$ & $\begin{array}{l}\text { Presentation of } \\
\text { student research } \\
\text { and seminar work, } \\
\text { presentation of } \\
\text { teaching methods }\end{array}$ \\
\hline Benefits & $\begin{array}{l}\text { Students have } \\
\text { access to } \\
\text { high quality } \\
\text { lectures, } \\
\text { Trainees } \\
\text { have the } \\
\text { opportunity } \\
\text { to listen to } \\
\text { teachers from } \\
\text { abroad }\end{array}$ & $\begin{array}{l}\text { Members } \\
\text { of family } \\
\text { medicine } \\
\text { departments } \\
\text { get support } \\
\text { in their } \\
\text { endeavours } \\
\text { to establish a } \\
\text { chair }\end{array}$ & $\begin{array}{l}\text { Joint } \\
\text { research, } \\
\text { better } \\
\text { ranking of } \\
\text { research } \\
\text { group }\end{array}$ & $\begin{array}{l}\text { Trainees have } \\
\text { access to } \\
\text { high quality } \\
\text { lectures, } \\
\text { calibration of } \\
\text { assessment } \\
\text { criteria }\end{array}$ & $\begin{array}{l}\text { Building } \\
\text { collaborative } \\
\text { attitudes }\end{array}$ & $\begin{array}{l}\text { Trainees have } \\
\text { access to } \\
\text { high quality } \\
\text { lectures, } \\
\text { calibration of } \\
\text { assessment } \\
\text { criteria }\end{array}$ & $\begin{array}{l}\text { Students learn } \\
\text { about each other's } \\
\text { achievements, } \\
\text { teachers have } \\
\text { the opportunity } \\
\text { to compare their } \\
\text { teaching methods }\end{array}$ \\
\hline Comment & $\begin{array}{l}\text { High level of } \\
\text { support from } \\
\text { the family } \\
\text { medicine } \\
\text { department } \\
\text { chair and } \\
\text { leadership of } \\
\text { the medical } \\
\text { school }\end{array}$ & $\begin{array}{l}\text { Support of } \\
\text { the dean of } \\
\text { the medical } \\
\text { school }\end{array}$ & $\begin{array}{l}\text { High level of } \\
\text { support from } \\
\text { the family } \\
\text { medicine } \\
\text { department } \\
\text { chair }\end{array}$ & $\begin{array}{l}\text { High level of } \\
\text { support from } \\
\text { the family } \\
\text { medicine } \\
\text { department } \\
\text { chair and } \\
\text { leadership of } \\
\text { the medical } \\
\text { school }\end{array}$ & $\begin{array}{l}\text { High level of } \\
\text { support from } \\
\text { the family } \\
\text { medicine } \\
\text { department } \\
\text { chair }\end{array}$ & $\begin{array}{l}\text { High level of } \\
\text { support from } \\
\text { the family } \\
\text { medicine } \\
\text { department } \\
\text { chair and } \\
\text { leadership of } \\
\text { the medical } \\
\text { school }\end{array}$ & $\begin{array}{l}\text { Long tradition of } \\
\text { cooperation and } \\
\text { mutual support }\end{array}$ \\
\hline
\end{tabular}


These one-day exchange visits consist of both formal and informal parts. During the formal part, selected teachers from all participating medical schools present their teaching methods, their teaching achievements or their developments as teachers. This is followed by presentations by the students, which includes presentations of their seminar works and/or their research projects. The formal part of the programme ends with a discussion, usually in mixed groups. The topics concentrate on learning about good practices/achievements in the study process and also what may be improved and how to achieve this. In the informal part of the study visit, the host students show the visitor students their faculty and their living situation. Meanwhile, the teachers engage in informal conversations about the teaching process, their experiences etc. The aims of such exchange visits are shared by students and teachers (Table 1).

One of EURACT's aims is fostering the exchange of experiences among its members in order to improve patient care in the member states. The exchange is conducted mainly by study visits of teachers to universities and conferences, and it is very vibrant in South Eastern Europe (23). Table 2 provides some examples of networking by the Department of Family Medicine of the Maribor Medical School.

\section{Conclusions}

Academic medicine is one of the pillars of the future development of FM/GP in Europe. Established departments of FM/GP led by a teacher who is a family physician/ general practitioner at each Medical School in Europe should provide students with knowledge and skills related to the core attributes of FM/GP. Teacher and student exchanges are able to contribute to the development of common curricula. A network of University FM/GP departments would facilitate such developments.
Authors' contributions: Conception and design: JK; Acquisition, analysis and interpretation of data: JK, ZKK; Drafting the article JK; Revising it critically for important intellectual content: ZKK.

Conflict of interest: The authors declare that they have no conflict of interest.

\section{References}

1. Allen J, Gay B, Crebolder H, Heyrman J, Svab I, Ram P. The European definition of general practice / family medicine, revised version 2011. Barcelona: WONCA Europe; 2011.

2. Heyrman J, editor. EURACT Educational Agenda. Leuven: European Academy of Teachers in General Practice; 2005.

3. Hummers-Pradier E, Beyer M, Chevallier P, EilatTsanani S, Lionis C, Peremans L, et al., editors. Research Agenda for General Practice / Family Medicine and Primary Health Care in Europe. Maastricht: EGPRN; 2009.

4. Sammut MR, Lindh M, Rindlisbacher B; EURACT-the European Academy of Teachers in General Practice. Funding of vocational training programmes for general practice/family medicine in Europe. Eur J Gen Pract. 2009;14(2):83-8.

5. Allen J, Svab I, Price E, Windak A. Framework for Continuing Educational Development of Trainers in General Practice/Family Medicine in Europe. Krakow: ZiZ; 2012.

6. Svab I. General practice teaching at the undergraduate level in Europe. Eur J Gen Pract. 1999;5:125-7.

7. Klemenc-Ketis Z, Vanden Bussche P, Rochfort A, Emaus C, Eriksson T, Kersnik J. Teaching quality improvement in family medicine. Educ Prim Care. 2012;23(6):378-81.

8. Rotar Pavlič D. Erasmus exchange in the field of family medicine in Slovenia. Acta Med Acad. 2012;41(1):47-51.

9. Seifert B, Svab I, Madis T, Kersnik J, Windak A, Steflova A, et al. Perspectives of family medicine in Central and Eastern Europe. Fam Pract. 2008;25(2):113-8.

10. Kersnik J. A need for an exchange on medical education between FM/GP stakeholders in Europe. Eur J Gen Pract. 2012;18(3):193-4.

11. Sammut MR, Lindh M, Rindlisbacher B. Funding of vocational training programmes for general practice/family medicine in Europe. Eur J Gen Pract. 2008;14:83-8.

12. Jurgova E. List of medical educational books used for teaching general practice and family medi- 
cine in the european countries. [cited 2013 Oct 5]. Available from: http://www.euract.eu/archive/ finish/22-education-a-training-materials/113list-of-medical-educational-books-used-forteaching-general-practice-and-family-medicinein-european-countries.

13. Wonca Europe [page on the Internet]. [cited 2013 Apr 30]. Available from: http://www.woncaeurope.org.

14. Krzton-Królewiecka A, Svab I, Oleszczyk M, Seifert B, Smithson WH, Windak A. The development of academic family medicine in central and eastern Europe since 1990. BMC Fam Pract. 2013;14(1):37.

15. Anon. Ten strategic points for Wonca Europe by 2010. [cited 2013 Apr 30]. Available from: http:// www.woncaeurope.org.

16. Svab I, Bulc M. Academic medicine: what does an outsider have to offer? Croat Med J. 2004;45(3):254-5.

17. Carelli F. Minimal Undergraduate Teaching Curriculum in Europe. In EURACT, editor. Ljubljana: EURACT; 2011.
18. Svab I. Possibilities of family medicine in medical education. Acta Med Acad. 2012;41(1):59-63.

19. Vrdoljak D. Teaching evidence based medicine in family medicine. Acta Med Acad. 2012;41(1):88-92.

20. WONCA Working Party on Education. Wonca global standards for postgraduate family medicine education [monograph on the Internet]. Singapure: WONCA; 2013 [cited 2013 Oct 5]. Available from: http://www.globalfamilydoctor.com/site/ DefaultSite/filesystem/documents/Groups/Education/WONCA\%20ME\%20stds.pdf.

21. Kezunovic Cvejanov L, Drecun M, Svab I. Primary care reform in Montenegro. Zdrav Var. 2013;52:247-54.

22. Klemenc-Ketis Z, Kersnik J. The role of the European Academy of Teachers in General Practice and Family Medicine in family medicine education in Europe - the experience of the University of Maribor. Acta Med Acad. 2012;41(1):80-7.

23. Pavlicevic I, Svab I. Family medicine defines its academic niche: the Split Initiative. Acta Med Acad. 2012;41(1):1-3. 